\title{
Pelos Caminhos da Rota Romântica: etnografia da constituição de um roteiro turístico no sul do Brasil
}

Moisés Kopper

(UFRGS)

\section{INTRODUÇÃO}

Em 1995, uma delegação composta de representantes de municípios do Rio Grande do Sul, órgãos de turismo locais e entidades públicas e privadas organizou uma agenda de visitações a vinte e sete cidades históricas do sul da Alemanha. Fundada cinco anos após o fim da Segunda Guerra Mundial, a Romantische Strasse - como foi definido o traçado que conecta tais municípios -, constituiu-se num arrojado empreendimento turístico que visava, em primeiro lugar, recriar a Alemanha como destino turístico no cenário internacional ${ }^{1}$, passado o nazismo hitlerista. Embora o trajeto já fosse conhecido desde o século XIX, quando era usado economicamente para conectar o rio Main aos Alpes bávaros², sua reinvenção romântica, nos anos 1950, caminhava lado a lado com os rearranjos políticos da nação alemã do pósguerra.

Inspirada pelo sucesso econômico da rota alemã, a delegação brasileira buscou recriá-la no sul do país, ao longo de um percurso de aproximadamente 240 quilômetros, que perfaz catorze municípios ${ }^{3}$, situados numa região até então conhecida pela denominação Serra Gaúcha ${ }^{4}$. Ainda no mesmo ano, junto a órgãos de turismo, associações e grupos comerciais, aconteceu o lançamento oficial da Associação dos Municípios da Rota Romântica - que permitiria ao trajeto turístico exercer representatividade política -; foram homologadas parcerias com a Secretaria Estadual de Turismo, a Câmara de Turismo, e a Empresa Brasileira de Turismo (EMBRATUR). Antes disso, porém, a ideia se propagara a outros países, como é o caso do Japão, que em 1982 fundou a Japanese Romantic Road. De geografias similares, suas concepções paisagísticas não poderiam ser mais diversas, se por paisagem compreendermos a interação entre homem, natureza e cultura (Ingold 2011).

A criação da Rota Romântica no sul do Brasil insere-se como parte de uma tendência nacional de crescimento do setor nos últimos anos, que chega ao seu auge 
em 2003, com a criação do Ministério do Turismo, e o início de sua regulamentação como diretriz de governo (Hall 2001; Carvalho 2000; Henz 2009). Até o início da década de 1990, o turismo vigorou como atividade secundária e difusa, tendo como marco apenas a criação da EMBRATUR, em 1966. Foi somente na gestão do então presidente Collor de Melo que um lento e progressivo período de expansão e valorização do turismo tomou forma (Cruz 2005). Apostar nessa atividade passou a representar a possibilidade de combater as desigualdades sociais e expandir o desenvolvimento econômico do país. Ao mesmo tempo, investir no desenvolvimento sustentável do turismo implicou ramificar seu planejamento, introduzindo os municípios como gestores locais, responsáveis tanto pela implementação de programas turísticos quanto pela descoberta de aptidões com claros benefícios econômicos (Henz 2009; Beni 2006). Por outro lado, ao governo federal caberia o papel de organizar e orientar a tomada descentralizada de decisões - diretrizes que passariam a configurar a Política Nacional de Turismo desde meados da década de 1990 e, nos 2000, o Plano Nacional de Turismo 5 .

A constituição da Rota Romântica ao longo do trajeto composto de catorze municípios de colonização alemã na região nordeste do Rio Grande do Sul situa-se no centro desse processo de consolidação da política turística no Brasil recente. Levando em consideração a emergência desse quadro macro-político, este artigo propõe elementos que permitam apreender os modos pelos quais um aglomerado de municípios é reinventado como uma "região" de múltiplas aptidões turísticas: que decisões e alianças levaram à sua fundação? Que agentes estiveram na base de sua consolidação? Como a sua configuração política estruturou-se sobre a incorporação de determinados atributos culturais que remetem, por sua vez, a tensões identitárias que estiveram na origem da imigração ítalo-germânica, ao longo do século XIX? De que modo esses valores, pelos quais os descendentes de imigrantes passaram a ser caracterizados, foram reordenados como atributos culturais, articulados através da gramática do mercado turístico, trazendo consequências não somente para a estruturação de diferentes modalidades ou aptidões turísticas no interior da região, como também para a recomposição étnica dos mercados locais?

$\mathrm{O}$ artigo divide-se em três partes: num primeiro momento, busca traçar o panorama geral em que se insere a grande narrativa turística, para pensar a emergência da Rota Romântica, simultaneamente como um problema antropológico e um empreendimento comercial bem-sucedido. Num segundo momento, atém-se ao percurso que conduziu à fundação da Associação dos Municípios da Rota Romântica, a partir da trajetória de Cláudio Weber, seu atual presidente. A seguir, debruça-se sobre a vida social de dois empreendimentos locais, suas reinvenções e estratégias quotidianas de sobrevivência, cujo sucesso passou a depender da incorporação do ideário turístico em torno do qual se constituiu a Rota Romântica.

\section{DA CULTURA AO TURISMO CULTURAL}

Desde os primórdios da imigração europeia no sul do Brasil, durante o séc. XIX, uma série de referências teóricas, midiáticas, literárias, etc. - valeram-se de narrativas de descoberta e domesticação da natureza inóspita a que estiveram sujeitos os assim chamados desbravadores, a fim de contar a saga desses imigrantes no novo 
território. Na antropologia, o conjunto dessas histórias - escritas ou narradas - costuma ser abordado no registro de um processo colonizador sobre as populações e as paisagens nativas, problematizando-as como estratégias de sobrevivência que permitiriam aos que chegam costurar um senso de coletividade baseado na reinvenção mais ou menos sincrética de elementos diversos como religiosidade, família, estilos de vida, imagens, formas de sociabilidade, usos do dinheiro, e por aí afora (Fouquet 1974; Oberacker 1957, 1978; Trespach 2010; Zanini 2007).

Sem negar a importância desses estudos para a compreensão da perdurabilidade e da especificidade dessas populações no tempo - bem como da natureza do vínculo entre a cultura local e a nacional - sugerimos que pouco se explorou sobre o estatuto da relação entre o homem e a natureza no que tange às imagens de colonização colocadas em jogo nesses processos migratórios, que tiveram por efeito, entre outras coisas, o estabelecimento de colônias italianas e germânicas na região do que se convencionou chamar, contemporaneamente, de Serra Gaúcha. De maneira particular, parece-nos que uma dimensão da maior relevância são as reinvenções modernas desses mitos colonizadores para a produção de uma sensibilidade econômica e turística dessas regiões. Como destacam Cousin e Réau, trata-se aqui de compreender o turismo enquanto um "fato social total", a fim de aclarar os jogos políticos, sociais, culturais, e de distinguir mais precisamente "les pratiques et motivations des touristes", assim como os "marchés et les métiers du tourisme" (Cousin \& Réau 2009: 12). De pronto, devemos acrescentar que este artigo preocupar-se-á sobretudo com este último, isto é, com os usos e estratégias decorrentes das políticas de turismo cultural, particularmente em dois municípios da Rota Romântica.

Por razões que ficarão evidentes ao longo do texto, a pesquisa que serviu de base para a produção deste artigo debruça-se, essencialmente, sobre duas cidades que compõem a Rota Romântica: Picada Café e Nova Petrópolis. Situadas ao pé da Serra Gaúcha, sua população, de números modestos - a primeira de cerca de cinco mil habitantes, a segunda de dezenove mil - manteve-se em relativo isolamento desde os primórdios da imigração alemã na localidade, o que permitiu, de alguma maneira, a reprodução inconteste da língua - o dialeto Hunsrück - e de uma série de práticas endógenas, capazes de fomentar a imagem de uma comunidade ou de uma nação (Avanza; Laferté 2005; Thiesse 1999, 2002).

Antes de avançarmos, contudo, é preciso debruçar-se sobre o processo de composição do trajeto e, por extensão, dos municípios que o perfazem. Constituída inicialmente em resposta à Região das Hortênsias ${ }^{6}$, de acordo com seu atual presidente, Cláudio Weber - de quem trataremos no tópico seguinte -, a Associação dos Municípios da Rota Romântica buscou no sincretismo cultural a justificação para sua existência enquanto produto turístico diferenciado:

Como nós tínhamos esse propósito de deixar os municípios de forte influência da imigração alemã em destaque e juntos, iniciou-se a Rota Romântica em São Leopoldo, e terminando em São Francisco de Paula. Permaneceu a cultura gaúcha, manifestada através de São Francisco de Paula, permaneceu a manifestação da cultura germânica, aí nós temos ainda a cultura japonesa em Ivoti e temos a italiana em todo o trajeto. Com isso nós guardamos todas as etnias, temos uma riqueza cultural muito expressiva e forte, e desta forma foi planejado e organizado o roteiro turístico Rota Romântica. 
Se o projeto de certo multiculturalismo - alimentado pelo não menos relevante cosmopolitismo de seus visitantes - estaria na base de toda a organização regional, operando como uma espécie de substrato comum, era preciso, ainda, justificar a presença de cada município, individualmente, através da invenção de conjuntos de particularidades. Em outras palavras, tratava-se de fabricar um argumento turístico capaz de tornar visíveis certas potencialidades, recursos e costumes passíveis de serem inventariados e adequadamente explorados em cada cidade. Se os elementos desse projeto poderiam ser buscados nos resquícios de uma germanidade reinventada pela memória narrada e vivida, era preciso forjar competências específicas que destacassem os municípios, essencializando seus atributos e harmonizando-os com os hábitos e práticas das populações locais.

Para os imigrantes teuto-italianos situados ao pé da Serra Gaúcha, o projeto de integração à cultura nacional sempre foi problemático e acompanhado de tensões entre a parte e o todo, entre o local e o global, entre a identidade regional e a identidade nacional (Oliven 1992). Diversos trabalhos apontam que a configuração dos laços étnicos locais desembocou na organização de comunidades de pertencimento cujas fronteiras passaram a ser tecidas a partir da evocação do germanismo local como uma espécie de contraponto ao risco, sempre presente, da assimilação à identidade nacional (Fouquet 1974; Oberacker 1957, 1978; Trespach 2010; Zanini 2007).

No processo de sua incorporação à nação brasileira, os próprios referenciais germânicos passam a ser vistos como reminiscências, sobrevivências de um passado incrustado nos objetos, na geografia, no tempo; enfim, passam a objetificar sua própria cultura, da mesma forma como entre os Daribi da Nova Guiné, estudados por Roy Wagner, "cargo" era o artefato conceitual que permitia a apreensão da alteridade a partir de dentro, numa espécie de metáfora analógica do conceito de cultura ocidental (Wagner 2010). Tal noção tornou-se, entre os colonos alemães dessas cidades, a palavra "costume", pela qual passaram a objetificar e tornar palpáveis como sobrevivências o até então não-pensado de sua realidade de vida cotidiana.

Não demoraria muito para que a indústria turística, que se instalou há poucos anos nessas localidades, se apropriasse dessa lógica para referir-se à possibilidade de comercialização das paisagens atávicas formadas pela justaposição desses "costumes". A inversão simbólica, que trazia o olhar de fora para pensar a própria identidade como o objeto resultante da confluência de uma série de elementos específicos, incrustou tais "costumes" nos modos de auto-percepção, símbolos e práticas reinventados do cotidiano. Como mostra Saskia Cousin, em Les Miroirs du tourisme, uma abordagem etnográfica acerca da recepção do turismo seria capaz de mostrar como, efetivamente, os moradores locais vivem com essas realidades, adequando as tensões e adequações entre os antigos e novos modos de vida, em sobreposição à realidade fabricada pelo turismo, sem que, contudo, uma implique na aniquilação da outra (Cousin 2008, 2011). Nas palavras de Cláudio Weber:

Na verdade, nossos alemães são melhores que os deles [Alemanha], porque somos alemães que comemos feijão com arroz. Nós nos transformamos em alemães brasileiros, porque temos esse jeito mais aberto, fazemos um churrasquinho no final de semana, que é uma liberdade que não existe lá. Somos muito receptivos, acho que é uma alegria causada pelo sol. E continuamos alemães no sentido da organização, da disciplina, na vontade de fazer bem feito, no talento para consertar, montar coisas. Isso é o mais rico: estamos no Brasil, temos uma cultura germânica e vivemos como brasileiros. É muito interessante. (...) Então, juntamos alguns elementos da cultura brasileira com a alemã e isso nos tornou em um produto humano muito rico, diferente ${ }^{7}$ (grifos meus). 
Os processos de emancipação política dos municípios que compõem a Rota Romântica trataram, de alguma forma, de transubstanciar tais atributos culturais - convertidos em "costumes" - em princípios políticos (Thiesse 1999, 2002). A esse respeito, o hino da cidade de Picada Café é ilustrativo. Composto em 1994, por Marco Aurélio Vasconcelos, trata-se de uma narração poética do processo civilizatório (Elias 1990) materializado com a chegada dos primeiros colonizadores alemães - ao mesmo tempo em que os atributos culturais passam a ser nomeados como objetos, "costumes":

Viemos de variados lugares / no rumo de uma terra prometida, / na busca de trabalho em novos ares / com o lema de vencer na nova vida. / Depois de enfrentarmos o perigo / das ondas, outros mais foram surgindo, / nas matas que nos deram para abrigo, / nas trilhas que, com fé, fomos abrindo. / Cruzando a mata virgem, sofrendo nas jornadas, / sentimos disparar os corações. / Com as armas dos arados, das pás e das enxadas / fizemos florescer as plantações. (Bis) / Na paz e com uniâo vieram os povoados, / que fazem a geografia atual / de núcleos e recantos bem cuidados / por gente que trabalha sem igual. / Nas curvas e rincões do Rio Cadeia / forjamos com amor e muita fé, / ao brilho de um sol que incendeia, / a linda história de Picada Café. / Trabalho, cortesia, nobreza de ideais, / decência, disciplina, fé, ternura. / Atávica alegria dos nossos ancestrais, / são traços que compõe nossa cultura. (Bis).

É possível contrastar a isso, o texto de apresentação do município, de composição muito mais recente, constante no site oficial, sob a seção história. Desde a primeira linha, a cidade é definida em relação a um projeto turístico mais amplo, do qual pretende ser parte; mesmo a digressão de caráter propriamente histórico é feita em associação direta à patrimonialização dos objetos, da cultura e dos roteiros de visitação que a engendram. Não menos importante, o tom romanceado, quase poético, que se sobressai no relato dos atributos naturais, projeta o leitor na imagética de uma perfeita harmonia entre o homem e o ambiente ${ }^{8}$ :

Picada Café integra a Rota Romântica e situa-se na encosta sul do Planalto Meridional, ao longo de um vale profundo pelo qual corre sinuoso o rio Cadeia, alimentado por inúmeros arroios e riachos. A paisagem é de montanhas com suas encostas cobertas de Mata Atlântica - grande parte, mata recuperada nos últimos cinquenta anos com uma flora variada na qual encontramos desde orquídeas e bromélias, até araucárias, caneleiras e ipês. A topografia acidentada e a riqueza hidrográfica fazem a região rica em cascatas e cachoeiras, de águas não-poluídas e balneáveis. (...) há quase cem anos Picada Café é identificada pelo moinho com roda de ferro, na curva antes de iniciar a subida para Nova Petrópolis. Atualmente, esse sítio integra o Parque Histórico Municipal Jorge Kuhn (...). A região foi, originalmente, ocupada por colonos alemães que aí chegaram a partir de 1844, dando origem a inúmeros povoados que hoje integram o município. (...) Picada Café tem uma população de 4.824 habitantes e uma expectativa de vida superior a 73 anos. Possui três escolas de ensino fundamental e médio; duas escolas de educação infantil; um pólo universitário do Sistema Universidade Aberta do Brasil-UAB; uma biblioteca municipal. Há cinco igrejas católicas e uma evangélica luterana, todas elas, somadas ao Parque e a inúmeras casas enxaimel, constituem o patrimônio histórico do município.

O relato - altamente seletivo, descritivo e inventariante - dos patrimônios municipais, está dirigido, notadamente, ao estrangeiro, àquele que, não conhecendo, pretende visitar a cidade. Destacando a qualidade de vida - e associando-a ao convívio pacífico e integrado à natureza -, a narrativa permite ainda fazer ressaltar os "costumes" apreensíveis nas atividades econômicas, cujos resquícios podem hoje ser apreciados no registro turístico da experiência do passado. Ainda assim, tal qual a noção de "cargo" implica no espelhamento inverso à de cultura, trata-se de uma paisagem econômica, religiosa e natural apreensível somente na medida em que faz 
referência aos sujeitos que a edificam e praticam; é nesse sentido que os objetos e espaços contam a história das localidades.

Da mesma forma, lê-se no site oficial da Rota Romântica, sobre o município de Picada Café:

Desde 1996, Picada Café integra o Roteiro Turístico: Rota Romântica (...). O município esmera-se no embelezamento ao longo da BR 116 e RS 815 com acostamentos limpos, plantio de Plátanos - árvore símbolo da Rota Romântica com taipas de pedra da roça e o colorido de milhares de pés de lírios, que intitulam Picada Café como Cidade dos Lírios. (...) Com grande potencial turístico, Picada Café possui roteiros por matas e trilhas que levam a cascatas de águas limpas (...); áreas de lazer junto ao Rio Cadeia e riachos; a vista do mirante; caminhada pelas praças, casas e Igrejas centenárias que contam a história das localidades. Além disso, possui natureza exuberante com muito verde e flores; relevo montanhoso, com pequenas planícies recortadas por arroios e pelo Rio Cadeia, paredões de pedra-grês (Arenito Botucatú) e rochas basálticas. Na indústria destacam-se os artigos em couro, móveis, esquadrias, calçados e malharias. As diferentes tendas ao longo da BR 116 possibilitam ótimas compras e a paisagem de plátanos e lírios proporcionam um passeio inesquecível. Na gastronomia vêm recebendo destaque os restaurantes, as casas comerciais e padarias, oferecendo aos turistas produtos típicos. Venha para a Cidade dos Lírios e conheça os atrativos que fazem deste pequeno lugar uma cidade aconchegante e acolhedora, oferecendo aos que a visitam, costumes e experiências de vida de anos passados (grifos meus).

Rochas, planícies e couros não são, aqui, simples artefatos em um mundo natural existente para além da intervenção humana. Tampouco, são o resultado transformado do trabalho do homem sobre a natureza, numa espécie de relação, constantemente revocada, de dominação. Ao contrário, que esses elementos figurem em um discurso turístico que compõe a paisagem de um lugar a partir de sua própria rusticidade, permite observar como sua naturalidade é incorporada como suporte para uma interação renovada com o sujeito-turista. Esse jogo interativo repousa em uma política de valorização do natural-como-agente, algo que se deixa ver, uma "potencialidade" (Comunello 2014) que se oferece à contemplação, ainda que mediado pelo cuidado humano. O morador nativo, agenciador dessa mesma paisagem, é redesenhado como plenamente integrado à natureza, conservador e administrador por excelência da naturalidade do lugar em que reside.

$\mathrm{Na}$ base desse projeto turístico estão, assim, noções de como integrar a natureza - em si mesma amorfa e abstrata - a um projeto político e rentável, em que sua exploração não se dá através do consumo ou da extração de recursos, mas pela sua conservação, sua patrimonialização. Esse processo, como veremos adiante, é operado por meio de tecnologias de mercado que transformam o natural em indicadores que permitem calcular a rentabilidade $e$ a expansão do negócio turístico. Em outras palavras, a relação entre natureza e cultura, reconfigurada na circulação de saberes e rotas que conectam municípios, é convertida em marcos de avaliação de um mercado turístico em efervescência.

\section{REINVENTANDO A NATUREZA: O FESTIVAL DA PRIMAVERA}

As ações governamentais desenvolvidas no âmbito do turismo - e que apenas recentemente foram observadas nesse registro como tais - situam cidades como Picada Café e Nova Petrópolis, melhor que quaisquer outras localidades da Rota Romântica gaúcha, no espectro de uma tensão, um fino e instável equilíbrio, entre moderno e 
antigo, entre história e memória. De um lado, a tentativa de rentabilizar a indústria turística enquanto um negócio está colocada na possibilidade sempre presente de emular o projeto ideal-típico da cidade-turismo Gramado. Ainda assim, se a ideia está presente, os modos de fazê-lo diferem substantivamente; fica claro que, entre o glamour de Gramado e o germanismo reinventado de Nova Petrópolis, há elementos importantes a serem considerados. Argumentamos que a produção social dessas diferenças ampara-se no próprio ato de reconfiguração das regiões enquanto "potencialidades turísticas" (Comunello 2014). Em outras palavras, parte significativa do processo de viabilização do turismo regional está na invenção de especialidades que singularizam as cidades que compõem o roteiro, de modo a agregar valor ao todo por seu caráter insubstituível.

De 26 de outubro a 4 de novembro de 2012, foi realizado, na cidade de Nova Petrópolis, um evento chamado Frühlingsfest - ou, alternativamente, Festival da Primavera -, proposto pela prefeitura municipal, através da Secretaria de Turismo, Indústria e Comércio, e pela de Agricultura e Meio Ambiente. Mesmo sem registros que permitam uma comparação direta entre a primeira versão, realizada até os anos 2000, e sua reedição, em 2012, torna-se factível supor que, nesse ínterim importantes mudanças conceituais tiveram lugar. A principal delas talvez seja o reordenamento dos jardins, ecossistemas e elementos estéticos, tidos como naturais, a partir do fomento da indústria turística ${ }^{9}$. Como uma das várias reportagens a respeito do festival deixa claro, "as atividades de jardinagem, que tanto eram valorizadas pelos imigrantes alemães, estão sendo retomadas com este evento"10. O que, talvez, seja menos evidente, é o seu realinhamento para a elaboração de uma paisagem turística ancorada na reinvenção da cultura e da história locais, que passam a estar à disposição, isto é, tornam-se apreensíveis, para o turista desejoso pela absorção dessa germanidade atávica.

Nesse processo, contudo, distintos elementos são justapostos e amalgamados num só fenômeno: a programação do festival incluía, por exemplo, a realização de oficinas de gastronomia com plantas, com o objetivo de rentabilizar o plantio de flores orgânicas; ou ainda o encontro de paisagismo regenerativo, que abordou "os temas da importância do poder das plantas em todas suas potencialidades de ação e a ligação entre o jardim e as pessoas, seus aspectos sutis, psicológicos e vibracionais"11. Há, da mesma forma, a ênfase no visual, através da realização de concurso de fotografias, chamado Fotografe Caminhos e os Jardins do Interior de Nova Petrópolis, que permitiu reconectar o urbano ao rural, o natural rústico experimentado no cotidiano dos colonos, com o natural romântico absorvido pelo urbano. Não menos importante, um minicurso buscou alinhavar técnicas fotográficas, como composição e enquadramento, ao registro de paisagens consideradas turisticamente exploráveis, como o Ninho das Águias e o Moinho Rasche - onde tiveram lugar as sessões. Por fim, a natureza foi ainda reinventada na exposição e comercialização de obras de arte que estivessem relacionadas ao campo temático dos jardins, através de quadros, telas, esculturas e bonecos.

O evento central do Festival, contudo, foi a realização do Desfile das Flores, organizado ao longo da principal avenida da cidade, em uma tarde de domingo. $\mathrm{O}$ acontecimento envolveu moradores locais, que enfeitaram seus carros com plantas e flores; organizações diversas, como grupos religiosos, de mulheres, de idosos, de corais; estabelecimentos comerciais, sobretudo floriculturas, supermercados e pequenos empreendimentos autônomos. 
Como se vê, em certo sentido, é toda a cidade que, em seu conjunto, se preparou como produto cultural destinado ao consumo turista. A sucessão de carros alegóricos, entremeada de veículos particulares enfeitados, ao som de bandinhas de música germânica local, terminou por compor um quadro particular, um retrato vívido, uma paisagem em movimento, em que não é possível nem desejável distinguir entre moradores, natureza e cultura. A integração dinâmica desses elementos convidava o turista a uma interação em diferentes níveis: da simples contemplação à completa absorção do cenário; é a própria experiência desse contato que está dramatizada na performance da cidade em deslocamento no ato do desfile.

Como vimos até aqui, a produção de uma espécie de aura romântica, capaz de culminar na conversão da germanidade local em atributo turístico, implica um ordenamento do espaço e das coisas que possibilite organizar não somente a arquitetura, mas informar a disposição de objetos e a patrimonialização de lugares, convertidos em paisagem capaz de ser apreciada como a revelação naturalizada do ancestralismo colonizador alemão. Essa reelaboração está particularmente presente no cotidiano de cidades como Picada Café e Nova Petrópolis, propulsionadas pela ainda insipiente indústria turística local. Nesse processo, novas identidades são produzidas, capazes de atingir novos públicos, num diálogo em que a vida do homem simples do interior, o colono alemão, repentinamente, adquire sentido em meio às cores vibrantes, ao bom humor, à hospitalidade, às festas, danças, roupas, músicas animadas, ao alemão aportuguesado, às interjeições que, paradoxalmente, denunciam o sincretismo cultural e as origens germânicas.

A seguir, veremos que um roteiro turístico não pode prescindir de uma organização politica que lhe serve de substrato. Não seria possível percorrer etnograficamente os caminhos da Rota Romântica sem atentarmos aos movimentos políticos que conduziram à formação da Associação dos Municípios da Rota Romântica (AMRR), organização que dá vida ao projeto do roteiro turístico.

\section{CLÁUDIO WEBER E A ASSOCIAÇÃO DOS MUNICÍPIOS DA ROTA ROMÂNTICA}

A história da Rota Romântica no Rio Grande do Sul, desde sua concepção até as consequências de sua execução, intersecta-se em diferentes momentos com a trajetória de Cláudio Weber, seu atual presidente. Natural de Nova Petrópolis, e empregado no ramo turístico desde a década de 1980, Cláudio viveu durante três anos na Alemanha, em uma das cidades que compõem o roteiro turístico da Romantische Strasse. Naquela época, Cláudio revezava a conclusão dos estudos de nível médio com turnos de trabalho esporádicos, onde aproveitava e empregava os conhecimentos do curso profissionalizante que realizava. De volta ao Brasil, investiu na criação de um programa de intercâmbio, capaz de facilitar a intermediação de jovens que, assim como ele, tinham interesse na realização de estágios profissionalizantes no exterior. Assim, em 1988, fundou a Associação de Fomento a Estágios de Brasileiros no Exterior (AFEBRAE) que, posteriormente, converter-se-ia numa agência de intercâmbios, isto é, capaz de gerar lucros decorrentes dessas intermediações. 
Cláudio se orgulha em contar que, desde então, já consagrou o intercâmbio de exatas duas mil e setenta e oito pessoas. De início, o programa concentrava-se sobretudo no setor primário, isto é, no aprendizado de atividades relacionadas à agropecuária que, então, com o retorno dos jovens, eram empregadas para a modernização das técnicas usadas nas suas cidades de origem. Muitos, inclusive, arriscavam-se a começar o próprio negócio, profissionalizando, ampliando e rentabilizando a atividade que, até então, já era exercida - embora de modo menos eficiente - por seus familiares.

Mais recentemente, contudo, Cláudio tem se empenhado, apesar da demanda ainda recorrente dos jovens que o procuram pela agropecuária, em deslocar esse eixo para novas áreas de interesse turístico, como o paisagismo, a fruticultura, a floricultura, o arborismo e a produção de vinhos. De maneira similar, há cerca de três anos o programa incorporou como um de seus eixos temáticos o ramo da gastronomia e da hotelaria, que busca recrutar jovens, em sua maior parte homens, para atuarem por cerca de um ano em estabelecimentos turísticos tradicionais do sul da Alemanha, notadamente aqueles que buscam recriar certa aura germânica como estratégia de consolidação no mercado. Além de regressarem municiados de novas tecnologias de atendimento e gestão de negócios, a parceria da agência com esses hotéis alemães permite o intercâmbio de pessoas e saberes de ambos os lados. Não é preciso grandes divagações para perceber que ambos os processos estão profundamente amarrados à reestruturação local do fenômeno turístico, especialmente no que se refere à sua elaboração enquanto produto comercial, capaz não de eliminar os lastros culturais locais, mas de potencializarem-nos como elementos indestrinçáveis dessa mesma arquitetura turística. Nas palavras de Weber:

O turismo é um negócio! É que nem tu abrir uma fábrica de calçados, é que nem tu abrir um restaurante. O turismo nada mais é do que um negócio que tu vai optar: olha, eu quero fazer calçados, eu quero trabalhar no turismo, o que eu quero fazer. Aí o turismo tem que gerar renda. Ele tem um fim comercial. Único e exclusivo. $O$ turismo no mundo inteiro tem um fim comercial. Resta saber como nós vamos aproveitar isso. E como se faz pra que isso realmente no meu caixa entre como dinheiro.

Antes da entrevista agendada com Cláudio, tivemos a oportunidade de conversar com sua secretária, que trabalha no escritório de intercâmbios coordenado por ele. Ela própria já participara do programa, tendo viajado em duas oportunidades para a Alemanha. Em ambas as ocasiões, inscreveu-se como Au-Pair ${ }^{12}$, a terceira e mais procurada modalidade, seja pela relativa maior facilidade em inscrever-se e ser aceita, seja pelo regime contínuo de aceitação dessas profissionais no mercado europeu. Nisso encontrou a solidariedade de várias outras adolescentes, instigadas, simultaneamente, pela expectativa de liberdade e independência, e por potencializar suas relações com o imaginário germânico, materializado no desejo de aprender a língua alemã e os costumes nativos, numa espécie de sublimação geracional em que seria possível, ao mesmo tempo, voltar para o passado e absorver o futuro daqueles que ficaram na Europa.

O lastro dessa germanidade reinventada na experiência dos sujeitos que realizaram o intercâmbio, numa espécie de troca contemporânea de uma identidade imaginada como situada no passado, constitui, de fato, um dos elementos essenciais para se compreender o caminho delineado na constituição da Rota Romântica no sul do Brasil. 
Em 1992, Cláudio Weber participou da fundação da Associação dos Ex-Estagiários e Amigos da Cultura Germânica, que passou a coordenar o programa de intercâmbio. Ao mesmo tempo, a sutil introdução do sufixo Amigos da Cultura Germânica permitiu estabelecer parcerias com duas associações alemãs interessadas na manutenção desse lastro identitário através do qual jovens brasileiros, suficientemente germânicos para comprovar sua genealogia, pudessem ser municiados de técnicas modernas, porque alemãs, de trabalho. E aqui não se trata de quaisquer técnicas, senão mais bem aquelas tidas como indesejáveis aos próprios europeus: o trabalho agrícola, hoteleiro e doméstico.

A reinvenção cotidiana da germanidade, potencializada pelo empreendimento turístico, expressa por meio de uma gramática desenvolvimentista, substanciada na narrativa da apropriação e exploração dos tempos e dos lugares êmicos, está na origem do projeto de constituição da Rota Romântica. A secretária de Cláudio, assim como ele próprio, vislumbrou a possibilidade de fazer do turismo sua profissão. Matriculada em um curso superior na área, seu projeto pode ser descrito, em grande medida, como a própria narrativa turística da Rota Romântica, cujas consequências estão ainda por ser produzidas nas cidades que a compõem:

Na verdade a população é que tem que se conscientizar que é importante... Aqui é uma região que, querendo ou não, tem muita gente ainda que trabalha na agricultura. Por que não, tem muita gente de cidade grande que quer conhecer, vivenciar isso, né? Num final de semana, uma cultura diferente... E é uma forma também de agregar algo à renda. Aqui em Nova Petrópolis já tem algumas pousadas... É que bem no interior assim o pessoal recebe bem... Além de não só mostrar o trabalho, a atividade agrícola, mas também mostrar a cultura do pessoal... As famílias se vestem bem típico alemã, e recebem, como se fossem vir pra colônia mesmo. Porque o turista que mora em cidade grande se identifica com isso, porque é diferente da realidade deles. (...) Só que na verdade o pessoal, quem é daqui... isso é engraçado, quem vive na cidade às vezes não vê com o olhar diferente. Mas quem vem de Porto Alegre pra cá se encanta. Eu quando vou pra Porto Alegre me desespero [risos]. Eu não sei, talvez a cidade seja diferente, mas o caminho pra Porto Alegre, aqueles casebres ali na BR 116, tá louco.

O depoimento da secretária condensa alguns dos elementos essenciais para entendermos a consolidação de um projeto turístico local. De um lado, ela aponta para o trabalho de convencimento constante dos moradores locais de que é possível e mesmo vantajoso tomar parte ativa nessa ideia. Muitas dessas pessoas não estariam preparadas para perceber tal necessidade - e aponta algumas razões para isso, como a falta de escolaridade e o estilo de vida rural que, paradoxalmente, seriam posteriormente reconvertidos em elementos culturais na reconstituição do espaço como lugar turístico. Finalmente, ela faz questão de demarcar as diferenças estéticas que a situam no interior desse projeto, sinalizando a aparente precariedade e desorganização das grandes cidades como o outro lado de uma cidade modelo, baseada na reinvenção orquestrada da natureza e de sua gente.

Em 1992, Cláudio Weber, paralelamente à agência de intercâmbios, resolveu abrir uma empresa de turismo, capaz de oferecer a logística necessária para vender grandes pacotes de viagem internacionais, sobretudo para a Europa, sua especialidade.

Eu tinha ônibus todos plotados com águias, um troço bem bonito. Comecei com 50 pila. Eu tinha dinheiro pra comprar uma máquina Olivetti, uma velha. Mas eu meti o peito. Consegui, me dei bem, cresci e ganhei uma barbaridade. (...) Eu consegui vencer numa cidade pequena. O que prova que não tem nada a ver, aonde tu estás. É o que tu vai fazer! Qual é o produto que tu vai ofertar. E como tu vai ofertar. 
Em cerca de 12 anos, sua empresa cresceu e, junto com o turismo local, passou a gerar grandes lucros. Ao mesmo tempo em que cidades na encosta da serra, como Nova Petrópolis, passaram a se configurar como polos turísticos através da reinvenção da identidade germânica - como o Outro distante e, não obstante, perto, com o qual o olhar do turista poder-se-ia confrontar - assim também os próprios moradores locais, ao menos aqueles que dispunham dos recursos para fazê-lo, eram convidados a reinventar sua germanidade em outro patamar: nas viagens para a Europa. Não, contudo, qualquer Europa; as propagandas davam conta de que os destinos turísticos eram, em geral, associados à paisagem idílica e bucólica da Romantische Strasse; a um encontro consigo mesmo através do Outro que permaneceu no Velho Mundo; enfim, uma viagem no tempo, uma memória fabricada no estímulo das sensibilidades e nas nuanças dos paladares, dos odores, dos sons e das imagens. Segundo Cláudio:

Eu soube sair na hora certa. Por quê? Porque o troço tava migrando pra internet. A função do agente de viagens, isso tem que estar ligado ao mercado, perdeu, hoje perdeu completamente o sentido. Hoje tu vai na internet. Tudo que tu quer buscar tu vai na internet. (...) Então quando eu percebi isso a minha empresa tava em alta, quando tu tem um negócio bom, bombando, é a hora de sair. Porque aí todo mundo quer o teu negócio. Bom, eu já ganhei o que tinha pra ganhar, e é exatamente isso que eu pensei. Eu vendi minha empresa bem. Eu tinha três interessados, e leiloei cara! Com carro, com ônibus, com marca, com tudo! 12 milhões de reais!

Até aquele momento, Cláudio não se envolvera diretamente na condução da Associação dos Municípios da Rota Romântica. Com a venda de sua empresa, ele reorganizou sua expertise comercial, passando a se dedicar à agência de intercâmbios, que lhe exigia uma estrutura logística mais enxuta, ao mesmo tempo em que mantinha os principais contratos do negócio anterior. Simultaneamente, passou a planejar sua aposentadoria: amparado por sua sensibilidade turística, empreendeu parte do dinheiro da venda da empresa na construção de um parque, na cidade de Gramado. Isso Ihe abriu possibilidades para passar de membro da Diretoria Executiva a presidente da Associação, cargo para o qual foi reeleito sucessivas vezes, e que ocupa até hoje:

To aqui quase dez anos, e não peguei financiamento, nada! Pelo contrário. O programa de intercâmbio eu sempre tive. Que é apoiado pelo governo, pelo consulado, então isso eu sempre fazia em paralelo. Então eu comecei a me dedicar um pouco mais a isso, e eu tava falando pra guria, agora é a hora de sair. Por que é a hora de sair? Porque hoje não tem mais fronteira. Cruzar a fronteira hoje é uma coisa cotidiana. Hoje é mais rápido ir pra Alemanha do que ir pra Foz de lguaçu de ônibus. Então, o sentido de fronteira, a concepção de outro país, atravessar a fronteira, não é mais como era a quinze anos atrás.

Nas horas vagas, Cláudio viaja o país na divulgação de seu programa de intercâmbio e, sobretudo, de sua expertise turística enquanto agente de viagens e idealizador da Rota Romântica. De alguma forma, sua trajetória à frente deste projeto confunde-se com as próprias ações desenvolvidas para o fomento do turismo local e, sobretudo, com os sentidos atribuídos a ele no cotidiano das cidades-membro.

Eu faço palestras pra, vamos dizer assim, divulgar e também criar uma expectativa positiva em cima de um ramo que todo mundo fala, e que poucas pessoas sabem como ele existe na prática, que é o turismo. Todo o mundo fala em turismo, mas eles não sabem como transformar o turismo num negócio. Então as minhas palestras são assim: o turismo como fonte de renda. Outra palestra que eu dou: o turismo regional e as vantagens que ele proporciona. Ao invés de trabalhar no individual, tu usa teu vizinho, aí convida o vizinho, vamos fazer uma coisa maior. 
Assim como o programa de intercâmbio contou com fortes investimentos de instituições como o Consulado Alemão no Rio Grande do Sul, e do próprio governo, através da Secretaria Estadual de Turismo, a Associação dos Municípios da Rota Romântica é mantida através de contribuições financeiras e logísticas dos municípios que a compõem. As ações por ela desenvolvidas ao longo dos primeiros anos, junto aos municípios, aliadas às parcerias com empresas e entidades públicas e privadas, implicaram na produção de um considerável capital simbólico, que permite pensar na Rota Romântica como uma espécie de selo certificador (Radomski 2010) da empreitada turística regional como um todo. Para a edição dos primeiros volumes da revista Rota Romântica, por exemplo, em parceria com a editora Verdeperto, não foram necessários investimentos. A tiragem de oito mil exemplares, que representou um custo de cerca de 60 mil reais, foi financiada exclusivamente por patrocinadores, tais como empresas, hotéis e estabelecimentos gastronômicos da região ${ }^{13}$ :

Eu hoje empresto o nome. Vem alguém querendo fazer uma revista, e eu empresto o nome pra eles e eles fazem a revista. Por exemplo, essa aí, não tem custo nenhum. Hoje a Rota tem um bom nome, registrado, e a gente faz parcerias. 'Ah, eu vou imprimir um folder', aí eu aceito e um cara vai querer patrocinar. Eu sempre acho alguém para patrocinar, porque ele quer colar a marca ali em cima. Então isso tornou um pouco mais fácil o trabalho.

Visto desta perspectiva, isto é, enquanto produto turístico capaz de potencializar as particularidades locais, é possível compreender que, da agência de intercâmbios para a Associação de Municípios da Rota Romântica, há um continuum baseado na troca de pessoas, ideias, saberes e fazeres. Em ambos os casos, é o aprendizado e a importação de técnicas tidas como autenticamente germânicas que permitirá a expansão desenvolvimentista local. Se para a agência de intercâmbios o que estava em jogo era mais bem a expertise técnica de certos ofícios, no caso da Rota Romântica trata-se, através de uma série de parcerias entre ambos os países (e entre os municípios da região), de recriar os vínculos dessa germanidade a nível local. Tanto antes quanto agora, é o turismo, com toda a sua maquinaria comercial, que costura a memória desse contato e dessa experiência teuto-brasileiras.

O cerne do projeto da Rota Romântica consiste em mobilizar e configurar uma "região" como alvo de políticas turísticas, o que inclui, certamente, uma série de estratégias de negociação junto às Secretarias de Turismo dos municípios envolvidos para a constituição de uma agenda comum de preocupações e ações específicas. Para voltarmos à fala da secretária de Cláudio, trata-se mesmo de fabricar uma espécie de consciência coletiva, no sentido forte do termo, que implique simultaneamente a militância das comunidades locais e a anuência dos políticos municipais. Se no primeiro caso a força dessa ligadura simbólica ancora-se na reinvenção do germanismo, poder-se-ia sugerir que, no caso dos municípios, trata-se de um verdadeiro projeto de convencimento acerca do turismo enquanto negócio, na propulsão das economias locais. Nas palavras de Cláudio:

É sabido hoje que esse caminho é certo, porque é impossível vender uma cidade sozinha. Você vai numa feira do centro-norte do país. Uma grande feira de turismo. Eu não posso chegar lá e vender uma cidade como Presidente Lucena. Ninguém. Agora, se eu chegar lá e vender a Serra Gaúcha, ou a Rota Romântica, que compõem 14 municípios, eu tenho mais facilidade em vender o meu produto. Então este é o cerne da questão. (...) O nosso trabalho é mais fazer que os municípios tenham ideias coletivas, que nós fomentamos, que a gente apresenta, que a Rota apresenta, e tentar fazer com que toda a região cresça junto, embora tenha alguns municípios que têm 
o expoente turístico muito maior que outros. A ideia sempre é trabalhar todo mundo num crescimento igual, pra que a gente possa vender uma região.

De um ponto de vista protocolar, a Associação dos Municípios da Rota Romântica é sediada num prédio histórico do município de Picada Café, e organiza-se em torno de uma diretoria executiva, composta de presidente, vice-presidente, administrativo, secretaria e tesouraria, que realiza reuniões mensais. Suas ações são planejadas anualmente, em encontros que ocorrem no mês de março, para as quais são convidados prefeitos, secretários de turismo e associados. Nessas ocasiões, são realizados seminários e grupos de trabalho que têm por objetivo discutir planilhas de ações previamente elaboradas pelo Conselho Administrativo da Rota Romântica. “E a gente sai daquele seminário com uma planilha feita, 'olha, estas são as ações 2012'. Então cabe a nós, Conselho Administrativo, colocar estas ações em prática”. Empiricamente, entretanto, isso implica a predisposição das prefeituras a rearranjos e interferências na estética paisagística e na concepção conceitual de cada cidade. Segundo o presidente da Associação:

Se você for olhar a BR116 antes do projeto turístico Rota Romântica, eu tenho foto disso aí, você vai ver um mato, uma estrada dominada pelo mato, que avança quase até a metade da pista... Hoje você tem uma pista harmonizada, arborizada, ajardinada, roçada, que por si só já justificava a existência da Rota Romântica. Quem passeia não quer ver mato, quem está passeando, quer se deliciar com a paisagem.

O caso dos plátanos que circundam a maior parte dos cerca de duzentos quilômetros de rodovias da Rota Romântica é paradigmático. Inicialmente planejados como sinalizadores do roteiro, de modo que o viajante pudesse orientar seu trajeto apenas pelas árvores, sua plantação sistemática deixa claro que há, igualmente, uma tentativa de aproximação para com a Romantische Strasse, ao torná-la árvore-símbolo do trajeto. Ao mesmo tempo, seu plantio passa a ser justificado desde um ponto de vista étnico-histórico, isto é, como tendo sido primeiramente trazidas as árvores pelos imigrantes alemães, ainda no séc. XIX e, posteriormente, florescendo de maneira natural, adaptando-se à paisagem local. Ainda de acordo com Cláudio:

Os plátanos não caíram do céu, eles foram plantados, isso foi uma ação, pra nós fazermos uma sinalização verde, natural. Ele foi escolhido como árvore-símbolo justamente porque dá unidade e confere ao caminho uma semelhança com a paisagem da Romantische Strasse europeia. Quer dizer, se não tivesse placa nenhuma, o turista iria se guiar pelos plátanos. Então os plátanos, no outono e inverno têm as folhas coloridas, o que atrai muitos visitantes, com as folhas caindo, esse cenário de romantismo, dado o nome Rota Romântica... O cenário de romantismo, o cenário de Serra, o cenário do aconchego, é isso que nós vendemos.

O trabalho junto com as prefeituras nem sempre repercutiu em aceitação direta. Da mesma forma, as ações desenvolvidas e propostas pela associação possuem graus variados de interferência na arquitetura paisagística e conceitual das cidades envolvidas. É Cláudio quem dá o exemplo dos pórticos de entrada e dos totens - uma espécie de placa ornamentada com telhados e floreiras, ambientada na arquitetura local-, que sinalizam ao passante a incorporação daquele município à Rota Romântica: 
O que a gente propôs pro município: olha, vocês têm paradas de ônibus horríveis. (...) Então, fomos na Brasken, na Suzuki, lá, que transforma plástico em madeira de plástico, nós juntamos a empresa com o gestor público e propomos que eles fizessem um acordo pra transformar as paradas de ônibus em paradas harmoniosas, dentro da sua arquitetura, que isso fosse uma coisa mais apresentável, mais bonita, mais arquitetônica, e ao mesmo tempo fosse um produto ecologicamente correto. (...) A parada de ônibus é hoje uma coisa muito linda, cheia de floreiras, todas elas com o conceito do ecologicamente correto.

Outras, contudo, como a realização de festas temáticas que constam no ciclo municipal de eventos, ou mesmo a adoção de certos símbolos como atributos identitários da cidade, incide diretamente sobre a percepção turística de cada município. Com isso, forjam-se zonas desiguais de exploração que, ao mesmo tempo em que potencializam certos atributos tidos como naturais ou específicos da localidade, especializam suas supostas qualidades e encerram a possibilidade de desenvolver outras aptidões turísticas. Ao fim e ao cabo, a adequação dessas distintas modalidades turísticas dependeria da agência mediadora desses experts, cuja habilidade estaria em, através de um olhar patrimonializador sobre os objetos, sujeitos e paisagens, produzir artefatos e relações capazes de torná-los passíveis de exploração comercial. É assim que Cláudio resume seu trabalho:

A minha função é organizar o município, deixar ele pronto pra receber os turistas. Como eles vão vender isso depois, é uma outra história deles. Aí quando eu vou estar descendo na BR 116, o que eu olho. Ah, tem um galho solto ali, vou mandar recolher. Poxa, a grama ta alta, eu ligo pro pessoal, vamos roçar. Tem muito lixo na beirada, então vamos fazer uma ação. Esta é uma preocupação. Tu entra num município, mas olha, poxa, vem cá, tchê, ta tudo seco, não tem flor, tem que plantar uma florzinha, vocês têm que plantar árvore de outono, não adianta plantar palmeira aqui no sul, palmeira é uma coisa do Nordeste... Então essa é a concepção. Ah, vai abrir um restaurante. O cara tem um péssimo atendimento, e está no centro da cidade. Nós temos que ir lá falar com o cara, que não tem conceitos... Então esse é o nosso trabalho.

Na sequência, trataremos dos impactos e ressignificações que a reorganização da relação entre cultura e natureza por meio do mercado turístico sugere na reelaboração dos próprios localismos - eles mesmos resultado de fluxos de outra ordem e época migratória. Tomaremos como ponto de partida as práticas de descendentes de imigrantes germânicos, atentando para suas estratégias de reinvenção quando confrontados com tais projetos, de inspiração econômica e turística mais amplos, no cotidiano de suas vidas. Como tais códigos, aparentemente desconexos e até mesmo irreconciliáveis, são colocados em diálogo nas próprias reformulações econômicas que esses descendentes de colonos forjam, fazendo uso estratégico dessa gramática para a propulsão local de seus negócios?

\section{A ROTA DO SUCESSO: RECONFIGURANDO SABERES COMERCIAIS E TURÍSTICOS}

Como vimos até aqui, a sustentabilidade do projeto Rota Romântica baseia-se, essencialmente, na cooperação dos municípios que dela fazem parte. Assim, uma breve análise do percurso histórico recente de Picada Café torna-se imprescindível para o entendimento da produção de uma vocação turística na região. Sua emancipação política foi, em grande medida, conduzida, fomentada e apoiada por empresários locais, insatisfeitos pelos ganhos marginais 
e o deslocamento de impostos para Nova Petrópolis - município ao qual Picada Café estivera vinculado até então. Poucos anos após o desmembramento seria criada a Rota Romântica e, não muito tempo depois, sua sede se radicaria permanentemente em Picada Café, no recém criado Parque Histórico João Jorge Kuhn. Ao mesmo tempo, uma série de outras políticas públicas, conduzidas ainda na gestão do primeiro prefeito municipal, trataram de realizar o tombamento de prédios antigos, sobretudo de igrejas centenárias e armazéns históricos. Nos colégios municipais, foram incluídas disciplinas e práticas de educação patrimonial; as aulas de educação física cederam lugar aos passeios, caminhadas e corridas, em locais estratégicos para o aprendizado da memória ambiental e histórica do município, ao mesmo tempo em que os momentos cívicos incluíam o aprendizado e exercício dos símbolos municipais (Sperb; Werle 2004).

Os anos 1990 assistiram ao florescimento e expansão das grandes indústrias calçadistas no município algumas das quais tornar-se-iam atores relevantes no cenário nacional, como a Calçados Dakota. Muito mais sutil, embora não menos importante, foi o surgimento de pequenos negócios baseados no crescimento da indústria turística, que rapidamente aumentaram em número e tamanho. O que é mais relevante ainda, tais empreendimentos puderam persistir no tempo - o que, em Picada Café, dada a conformação do mercado e da população, sempre foi prática difícil e desafiadora. Sua expansão tem a ver, como parece, com a incorporação de um fino discurso turístico, que passou a estar embutido nos próprios empreendimentos comerciais que surgiram nessa época, ao passo em que foi incorporado por outros que souberam reestruturar adequadamente suas táticas comerciais e se adequar aos novos tempos.

O que essas mudanças trouxeram, essencialmente, foi a ideia de que, antes de atender a um mercado interno que pouco crescia e se desenvolvia, urgia que se pensasse em estratégias de abordagem aos visitantes, viajantes e turistas. O maior desafio consistia em converter Picada Café, de uma cidade de passagem à BR 116, para um município capaz de oferecer produtos turísticos e comerciais específicos, baseados na reinvenção e exploração de sua natureza e sua gente. Tal é o caso de padarias, lojas de artesanato, de couro, floriculturas, restaurantes e pousadas, em sua maior parte situadas às margens da BR 116.

A trajetória comercial da hoje chamada Tenda do Umbu, vista à luz das estratégias desenvolvidas pelos seus principais dirigentes, é emblemática desse processo de reconfiguração turística da região. Em conversa informal com um de seus coordenadores, atualmente eleito vice-prefeito municipal, ele narra o processo histórico que levou à fundação dos negócios da família.

O Nicolau Rückert, meu avô, ele tinha um grande pedaço de terras, e cada um dos filhos herdou uma parte. E aí o Elói, um dos filhos, quando ele tinha 14 ou 15 anos, ele começou a vender coisas na praça. Laranjas, bergamotas, rapaduras, que tinha pouco na época, que ele pegava em Presidente Lucena. Passava um carro e ele oferecia. Na época não havia ninguém que vendia coisas à beira da estrada, então eles fizeram dinheiro.

Em pouco tempo, Elói Rückert, de vendedor de rapaduras, reorganizou seu negócio, construindo uma tenda de madeira, ao lado de uma praça e de uma árvore histórica, um umbu, na localidade de Picada Holanda. 
E começou a vender bem, vendia, vendia, o que se vendia na estrada. O velho comprou uma caminhonete de uns ciganos, essas um pouco maiores que as Saveiro de hoje. Era verde escura, quase preto. E ele sempre estava bêbado, mas ia comprar laranjas, pensa bem. Então ele pegava a caminhonete pra poder sair e passar nos botecos. Aí ele ia até Linha Nova, Presidente Lucena, e vinha carregando laranjas. E começou a engrenar o negócio. Aí o Elói já começou a vender laranjas em saco, pras pessoas da serra, Porto Alegre... Ele fazia sacos com as melhores laranjas e vendia em Porto Alegre, Caxias... E ele ganhava cada vez mais serviço com a caminhonete.

Algum tempo depois, diante do sucesso crescente do empreendimento, o pai de Elói tratou de construir um posto de combustíveis, ao lado da tenda que já existia. Até aquele momento, apenas outro concorrente havia se aventurado nesse ramo naquelas imediações; ainda assim, seu negócio distava em pelo menos 10 quilômetros de Picada Holanda. Depois de realizado o serviço militar, prestado em São Leopoldo, pelo período de um ano, Elói retornou à tenda, onde assumiria as rédeas da empresa e introduziria o comércio de artigos de couro.

A inversão nas estratégias econômicas dos negócios da família corresponde, grosso modo, à ampliação do público consumidor - que até então se destinava aos passantes, através da tenda, ou ao suprimento de combustíveis para o mercado interno. Cerca de dez anos transcorridos, durante a construção de um prédio novo para onde seria redirecionada a tenda, Elói sofreu um acidente que o deixou paralisado, em estado vegetativo, permanecendo assim até hoje, em leito doméstico. Os filhos, contudo, seguiram com os negócios da família, embora não sem conflitos internos. Os constantes desentendimentos fizeram-nos dividir as franquias abertas ao longo dos anos, de modo que a um deles coube a gestão do posto de combustíveis e ao outro a tenda, que seria acrescida, subsequentemente, de um restaurante.

Desde a introdução de artigos de couro - que não se restringem à indumentária, abrangendo ainda desde artesanatos, passando por artigos do imaginário gaúcho, como botas, chapéus, etc., e presentes em geral - a Tenda do Umbu converteu-se em um ponto de encontro de turistas, particularmente de motoqueiros. Situada estrategicamente na entrada da cidade, no sentido capital-interior, o grande e velho umbu, que abraça simbolicamente os negócios da família em conflito, reconverteu-se, metonimicamente, num objeto capaz de perspectivar as experiências naturais dos visitantes. Do outro lado do empreendimento, uma praça em meio à mata nativa serve de palco para a realização de churrascos, em quiosques alugados pelos proprietários. Ao lado do umbu, um pequeno palco recebe músicos aos finais de semana, para entreter os visitantes; finalmente, um parquinho de diversões atende aos desejos das crianças. Sem poder contemplar os resultados de seu empreendimento e o desenvolvimento de seus projetos pessoais, interrompidos pelo acidente que o deixou incomunicável, Elói Rückert, apesar de todos os contratempos e desencontros, possibilitou a ressignificação do próprio nome-fantasia que fundou a empreitada da família: da tenda construída na domesticação e apropriação da natureza, para a experiência da natureza, da perspectiva de seus novos clientes-turistas.

Essa experiência de reordenamento econômico contrasta em importantes pontos com a vida social dos negócios da Família Kunz, situados, igualmente, à beira da BR 116, a cerca de dez quilômetros da Tenda do Umbu. Glodomiro, Mário e Jurema Kunz foram introduzidos, desde muito cedo, nas lidas do campo, acompanhando sua mãe, Irma, quotidianamente, na roça. Um tanto heterodoxo para a época, era a matriarca quem lidava com as 
ocupações da rua; Walter, o pai, sempre trabalhara em casa, onde mantinha uma selaria que, posteriormente, passara a incluir, também, uma sapataria. A partir dos anos 1960, a confecção de selas completas entrou em decadência. O cavalo foi progressivamente substituído pelas bicicletas, como objeto de desejo e consumo dos jovens, ávidos por independência econômica.

Nessa época, a aquisição de terras era o indício mais visível da rápida ascensão e prosperidade nos negócios. Era para isso que o casal Walter e Irma trabalhava incessantemente. Afinal, era isso que permitia agregar valor ao nome da família, na medida em que representava a possibilidade de herança direta entre as diferentes gerações. Não menos importante, consistia numa espécie de moeda viva, em todo o caso tida como mais segura para o investimento do dinheiro do que os bancos: suficientemente concreta e material para ser apreciada por todos, suficientemente abstrata e estável para evitar a depreciação. Obviamente, tais práticas transformaram-se em pouco tempo num esporte excitante (Elias; Dunning 1992), vale dizer, deram margem a competições, rivalidades e disputas pelos melhores pedaços de terra - e eram tão mais efervescentes quanto incluíssem uma rede acionada em função de empréstimos e concessões de crédito. Em poucas palavras, as compras, arrendamentos e disputas por terras constituíam-se, em grande medida, numa linguagem metonímica em que eram negociadas as hierarquias e posições de poder dos homens - encarregados de fazê-lo - nessa sociedade (Journet 2005).

Entre uma aquisição de terras e outra, Walter seguia com o desejo de ampliar seu negócio, transformando-o numa espécie de mercearia ou armazém. Para isso, precisava de um terreno bem localizado e de mais capital. Glodomiro, o primogênito, narra esse processo: “E o que ele tinha? Ele já tinha uma loja de sapatos, ele vendia tecido em metro, porque ninguém comprava roupa pronta, e estava começando um pequeno armazém. Ele ia ampliando aos poucos, sempre agregando mais e mais. E ele lucrava bastante". Os caminhões eram despachados de São Paulo, ou então de Porto Alegre, e costeavam a BR 116, parando para quem sinalizasse. Já os chapéus de palha eram fornecidos de Garibaldi, Flores da Cunha, bem como outros municípios da serra. "Aí nós compramos de um atacado, que passava, que era o Berinzoni, que vendia mantimentos, foi o primeiro, Carlos Berinzoni, de Porto Alegre. Ele ficava na Julho de Castilhos. Depois veio a Sogenalda. Depois vieram outros...", sugere Glodomiro.

A ascensão econômica e social da família Kunz só não foi mais rápida que a morte prematura de Walter, aos 44 anos, em 1969, por conta de um derrame cerebral. Glodomiro, o filho mais velho, tinha então apenas 21 anos; havia recém saído do quartel, onde prestara o serviço militar obrigatório pelo período de um ano. A realização do inventário da família Kunz foi uma espécie de evento catalizador de vários outros acontecimentos. $\mathrm{O}$ comércio recémaberto por Walter foi registrado no nome da matriarca, Irma Kunz; aos três filhos coube o papel de empregados formais, sendo registrados como sócios e pagando previdência social. Quando em vida, Walter havia flertado com a possibilidade de trazer mercadorias de Porto Alegre, através dos ônibus intermunicipais que conectam as cidades da BR 116 à capital. Para Glodomiro, contudo, esta era uma experiência nova, absolutamente inusitada.

Em pouco tempo, à medida que o primogênito adquiria o traquejo necessário para se dar bem nos negócios, o comércio progrediu e se expandiu. Outras firmas foram agregadas ao leque de fornecedores, assim como novos produtos. Em Porto Alegre, Glodomiro passou a adquirir roupas prontas, como camisas e calças de marcas como 
Freeley e West Top, em estabelecimentos como Confecções Wolf ou mesmo Fontana Di Trevi. Com o sucesso e a visibilidade, Os Kunz, como ficou conhecido o negócio, passou chamar a atenção do principal concorrente, situado do outro lado da BR 116. Além disso, Glodomiro forjou uma extensa rede de distribuição, para quem comercializava e negociava tais mercadorias. Era no interior desse circuito que era capaz de converter laços sociais duradouros em frutos de negociações mercantis, sem que uma minasse a outra (Zelizer 2009).

O período de 1970 até 1990 foi, em poucas palavras, marcado pela prosperidade econômica. Ainda assim, com o aumento da concorrência, era preciso um plano sistemático de expansão, que veio, efetivamente, com a construção de um edifício totalmente novo, nos fundos de onde ficava o então mercado. Do velho prédio de madeira, de aproximadamente 70 metros quadrados, para um empreendimento de dois pavimentos, cerca de dez vezes maior, um dos quais fazia às vezes de depósito.

O mesmo circuito de obtenção de crédito, necessário à aquisição dos bens que demarcam a passagem à vida adulta e às responsabilidades familiares - dos quais, como vimos, a terra constitui o recurso mais importante - foi reinventado para a ampliação da rede de clientes do mercado. As dívidas dos clientes do mercado eram anotadas e registradas de acordo com a modalidade de compra e a reputação das famílias. Quem fosse cliente assíduo, de boa índole e comportamento, de descendência alemã - em geral comprovada através do sobrenome e da comunicação em dialeto local - e, ademais, fizesse seus ranchos semanais ou mensais no estabelecimento, tinha direito a uma caderneta individual, registrada no nome do patriarca ou sobrenome da família. Aos que tivessem todos esses requisitos, embora não fizessem compras substantivas com certa regularidade, destinavam-se as fichas, registradas por nome do cliente, em que se anotavam as dívidas a lápis - sendo apagadas com a quitação. Por fim, aos clientes regulares que comprassem miudezas era propiciado, ainda, o recurso ao caderno - de fato, um caderno universitário onde, em cada canto, eram escritos o nome, a data e o valor da dívida. Algumas associações e grupos também tinham direito à caderneta, como é o caso de paróquias religiosas e empresas parceiras. Em geral, era também nas cadernetas que constava uma breve descrição da mercadoria adquirida - usualmente mantimentos e outros recursos para a manutenção da casa e da alimentação familiares.

De modo geral, a concessão de crédito seguia a rede de conhecidos, familiares e pessoas da comunidade; poderiam ainda funcionar a partir de indicação. Com o tempo, contudo, foram obrigados a incluir os migrantes, que vinham se assomar na cidade em função da boa oferta de empregos causada pela expansão da indústria calçadista. Alguns deles nem sequer possuíam sobrenome ou qualquer indício que comprovasse sua descendência germânica, o que tornava ainda mais problemática a negociação do crédito.

$\mathrm{O}$ aumento da concorrência, sobretudo depois da instalação de uma grande rede de supermercados na cidade, não foi o único responsável pela decadência dos negócios da família Kunz. Antes de justificar a derrocada econômica por um suposto fracasso na renovação das estratégias, é preciso primeiramente entender o que motivou a falta de interesse em manter-se como competidor potencial naquele mercado. Constituindo-se, desde o começo, enquanto comércio de família, sua rede de clientes estava baseada, sobretudo, na capacidade de ação e funcionamento do circuito de reciprocidades locais. Em outras palavras, tratava-se de um negócio eminentemente 
barrial, estruturado menos sobre a base de relações mercantis que de sociabilidade e convívio quase cotidianos. Como a fronteira entre o público e o privado jamais estivesse nitidamente definida, muitos dos amigos, conhecidos e próximos à família eram, como já vimos antes, igualmente, clientes, e vice-versa; quem não o fosse, em pouco tempo o seria, e tal era a condição, em alguma medida, para ser digno da concessão de crédito.

Havia, além disso, razões de caráter técnico a justificar o declínio das vendas. Pouco tempo depois do Plano Real, o comércio da família foi estimulado a adotar a caixa registradora: “Nós não regredimos, apenas mantivemos o mesmo estoque, e deixamos crescer. Aí que nós percebemos. Nós pagávamos muito imposto; era tão fácil apertar os botões, ao invés de usar a caneta e o papel". Com efeito, a caixa registradora era apenas o primeiro indício técnico de que um reordenamento dos comércios locais - até então exclusivamente voltados à população dos arredores - estava em marcha. Tais reestruturações tinham subjacente um novo perfil de consumidor: não mais o vizinho de porta - com quem, além de vender, era possível conversar a ponto de perder-se no tempo-, era preciso agora atingir o cidadão-turista, o estrangeiro, o passante.

O empreendimento foi definitivamente fechado em março de 2007. Como se tratasse de um negócio de família, e dados os atravessamentos de honra e rivalidade que permeavam os diferentes circuitos da cidade, bem como as relações dos sujeitos entre si, Glodomiro optou por fechar as portas após vender todo o estoque - ao invés de anunciá-lo para que algum concorrente pernicioso pudesse arrebatá-lo. Da mesma forma, a partilha do montante decorrente da venda dos produtos foi realizada entre os três sócios - Glodomiro, seu irmão Mário e sua irmã Jurema, os mesmos que, em 1969, com a morte do pai, foram inscritos como funcionários de Irma, a matriarca da família, que jamais chegara a conduzir o negócio. Irma permaneceu, ao longo do período de funcionamento do mercado, trabalhando na roça, seguindo com os afazeres que sempre a ocuparam.

Com o fechamento, Glodomiro tratou de, em pouco tempo, reorganizar suas estratégias comerciais. Aproximadamente três anos passados, ele reabriu, no mesmo prédio - ao menos em uma parte dele - um pequeno bazar de variedades, em sociedade com sua filha, conduzida a atuar nos negócios da família e a levar adiante seu legado. Reorganizado nos novos tempos econômicos, buscando por novos nichos de mercado, a nova atividade permitiu a Glodomiro retomar velhos ossos de ofício: regularmente, ele retornou às suas viagens a Porto Alegre, onde busca novos e velhos tipos de mercadorias adequados ao novo negócio, ao mesmo tempo em que amplia sua cartilha de fornecedores e repassa sua expertise comercial às novas gerações.

\section{CONSIDERAÇÕES FINAIS}

A antropologia do turismo que floresceu nas últimas décadas pode ser dividida, para fins analíticos, em duas grandes áreas. De um lado, buscou-se entender suas origens, focando nas motivações subjacentes ao deslocamento de turistas (MacCannell 1976; Nash 1981, 1996). De outro, atentou-se para os seus impactos na reconfiguração dos locais afetados pelo turismo (Bendix 1989; Bruner 1987; Bruner; Kirshenblatt-Gimblett 1994; Urry 1990; Gamper 1981; Leong 1989). Uma terceira via, que explica o fenômeno a partir de um viés histórico (Adler 1989; Towner; 
Wall 1991; MacCannell 1976), concentrou-se no entendimento de suas origens modernas para problematizar por que certos turistas procuram determinados destinos e experiências em detrimento de outras. Em todos esses casos, entretanto, pouca atenção foi dispendida na análise de projetos que visam construir destinos turísticos, em parte porque parecia suficiente apontá-los como vetores capitalistas que, uma vez implantados de cima para baixo, minariam com as culturas locais.

Contudo, análises baseadas em material etnográfico e entrevistas em profundidade, a partir do que construímos o argumento ao longo deste artigo, deixam claro que projetos turísticos não apenas emergem em contextos de diálogo entre planejadores e habitantes locais, como também são vistos como necessários e mesmo desejados pelos moradores como estratégias que permitem propulsionar seus negócios (Stronza 2001). Projetos turísticos, como a Rota Romântica, configuram-se como importantes plataformas de reestruturação da economia, da indústria e da política locais, na medida em que, como vimos até aqui, eles não apenas não excluem como não podem prescindir do apoio e do engajamento ativo e constante de moradores locais.

Nesse processo, entretanto, cidade e habitantes, natureza e cultura, são reinventados, no interior de novas relações que permitem auferir os ganhos e perdas que a indústria turística poderá aventar à região. Os vínculos entre essas variáveis passam a ser redefinidos no registro de uma integração harmônica, em que o convívio em sociedade é homologo à relação do sujeito com as plantas, árvores e animais. Não menos importante, o próprio caráter exploratório e objetificável dessa natureza passa a ser questionado: não somente o homem, mas também os objetos, lugares e coisas passam a ser vistos como agentes que, no cenário turístico, podem contar e exalar narrativas sobre a cidade, os moradores, sua história.

Ao longo deste artigo, vimos como a implementação de um roteiro turístico, na Serra Gaúcha, desencadeou profundas restruturações políticas, econômicas e sociais para os catorze municípios que perfazem o trajeto. Concentramo-nos, inicialmente, em conjuntos de evidências documentais e empíricos coletados em duas cidades Picada Café e Nova Petrópolis - que, ao se colocarem o desafio de pensar o turismo local, continuamente reinventam sua história, seu passado, sua terra. Vimos como fazer parte desse projeto implica a restruturação dos costumes locais como artefatos culturais, da paisagem como natureza, e da cidade como cenário onde se concretizam essas relações.

Subjacente a essas reformulações, estão noções que - como argumenta Cláudio Weber, atual presidente da Associação dos Municípios da Rota Romântica -, enxergam no turismo um negócio altamente rentável, capaz de propulsionar o desenvolvimento econômico e social da região. Ainda assim, como procuramos demonstrar, o trajeto que conduz à implantação e expansão bem sucedida do turismo implica a constante busca de "potencialidades" (Comunello 2014), isto é, de objetos, histórias, lugares e pessoas disponíveis e capazes de ser rearranjadas no interior de uma narrativa turística. Nesse sentido, e o processo de implementação da Rota Romântica como roteiro deixa isso evidente, é no interior desses espaços de múltiplas manobras possíveis que são fabricados os contornos do turismo local. A incursão pela vida social de dois microempreendedores conta, ademais, de outra perspectiva, como essas mudanças são sentidas, experimentadas e colocadas em prática no cotidiano dos moradores locais situados 
na malha da invenção turística. Atentar para esses diversos processos, encadeados pelas lentes privilegiadas da antropologia, auxilia a iluminar suas consequências e impactos no cotidiano das populações para as quais cultura passa a ser o substrato de sua identidade, o indicador do desenvolvimento regional, definível na interface com o turismo local. 


\section{NOTAS}

1 De acordo com o site oficial da Romantische Strasse (http://www.romantischestrasse.de/index.php?id=154\&L=0), o período logo após o fim da Segunda Guerra Mundial assistiu ao crescimento exponencial do turismo internacional. Este desenvolvimento foi consequência da nova ordem internacional, da estabilidade social e do desenvolvimento da incorporação do lazer nas rotinas de trabalho ocidentais. A recuperação econômica, especialmente na Alemanha e no Japão, além da elevação dos níveis de renda, fez surgir uma classe média estável, que começou a se interessar por viagens.

2 Romantische Straße a Rota Romântica alemã, se estende de Würzburg - às margens do rio Reno - até Füssen - aos pés dos Alpes. De acordo com o site do projeto, "com as belas cidades medievais ao longo da Rota Romântica era possível mostrar uma nação alegre, multifacetária e imersa na história da União Europeia" (https://www.romantischestrasse.de/showpage.php?SitelD=147\&lang=pt]).

3 São eles: São Leopoldo, Novo Hamburgo, Estância Velha, Ivoti, Presidente Lucena, Picada Café, Dois Irmãos, Linha Nova, Santa Maria do Herval, Morro Reuter, Nova Petrópolis, Gramado, Canela, São Francisco de Paula.

4 A Serra Gaúcha refere-se ao aglomerado de algumas cidades situadas na região nordeste do estado do Rio Grande do Sul que, em função de certos atributos tidos como naturais, confluiriam na formação de uma região com grande potencial turístico. Um breve exame de sua constituição histórica revela como elementos como o frio, a colonização europeia, a geografia acidentada dão origem, através de políticas mais ou menos focadas no mercado turístico, a noções como "hospitalidade, beleza e boa comida", hotéis "aconchegantes", "belas" garrafas de vinho e "pedacinhos da Europa" (citações extraídas de http://www.serragaucha.com.br).

5 O Plano Nacional de Turismo constituiu-se como o principal instrumento de planejamento do Ministério do Turismo. Seguiu-se à sua implementação, em 2004, o Programa de Regionalização do Turismo - Roteiros do Brasil, que visava reforçar a vocação descentralizada da emergente indústria turística, enfocando sua regionalização como recurso à diferenciação comercial.

6 A Região das Hortênsias é uma comarca turística que se refere ao traçado formado pelas cidades de Gramado, Canela, Nova Petrópolis e São Francisco de Paula, ligadas pela RS 235. A flor que dá nome à região é a hortênsia, cuja coloração azulada é atribuída à grande quantidade de ferro no solo da Serra Gaúcha.

7 Declaração de Cláudio Weber em entrevista à revista Verdeperto Rota Romântica, vol. 1, 2011.

8 Trata-se, aqui, essencialmente, de um vínculo do homem com a natureza que inverte as premissas do que seja sujeito e do que seja objeto. Com isso, sugiro que há uma inflexão na maneira como a paisagem e a natureza se inserem nas narrativas locais: de um lado, a ideia de que há, subjacente à imigração, um processo colonizador, propõe igualmente que se trata de uma domesticação da natureza, de sua objetificação como condição para a existência de um sujeito que a transcende - o próprio imigrante. De outro lado, o que a constituição de zonas turísticas, aliadas a instituições como a Rota Romântica e a nomenclaturas como a Serra Gaúcha, parece sugerir é que se trata de uma subjetificação da natureza, de um sujeito que só existe na medida em que compartilha com a natureza uma experiência subjetificadora, uma perspectiva desde onde se colocar no mundo.

9 É nesse registro que podemos compreender as palavras do prefeito municipal, num primeiro momento aparentemente retóricas, em entrevista a um jornal local: "Nossa cidade é um tapete florido naturalmente. Temos o cuidado de sempre termos flores em todos os espaços e não só na área central da cidade. Nossa população merece ter a mesma alegria do despertar das flores" (grifos meus).

10 Trecho extraído de: http://www.novapetropolis.com.br/festivaldaprimavera/noticias.php?id=71. Acessado em 20 de janeiro de 2015.

11 Trecho extraído de: http://www.novapetropolis.com.br/festivaldaprimavera/noticias.php?id=71. Acessado em 20 de janeiro de 2015

12 Au-Pair refere-se ao homógrafo francês, que significa a par ou igual, indicando que a relação se destina a ser entre iguais. Tratar-se-ia, dessa forma, de um membro temporário da família, e não propriamente de um doméstico, embora tais limites sejam, possivelmente, problemáticos na prática.

13 Atualmente em sua quarta edição, a revista Verdeperto Rota Romântica é editada semestralmente e mantida por meio de patrocinadores locais. Sua distribuição é gratuita e dirigida a potenciais turistas e viajantes. Suas estratégias de marketing incluem desde amplas ilustrações coloridas, fotografias elaboradas, até matérias que entronizam os potenciais turísticos, culturais e históricos das diferentes regiões que compõem a Rota Romântica. 


\section{REFERÊNCIAS BIBLIOGRÁFICAS}

ADLER, J. 1989. “Origins of sightseeing". Annals of Tourism Research 16: 7-29.

AVANZA, Martina; LAFERTÉ, Gilles. 2005. “Dépasser la 'construction des identités'? Identification, image sociale, appartenance". Genèses 61: 134-152.

BENDIX, Regina. 1989. “Tourism and cultural displays: inventing traditions for whom?". The Journal of American Folklore 102: 131-46.

BENI, Mario Carlos. 2006. Política e planejamento de turismo no Brasil. São Paulo: ALEPH.

BRUNER, Edward. 1987. "Of cannibals, tourists, and ethnographers". Cultural Anthropology, 4: 438-45.

BRUNER, Edward; KIRSHENBLATT-GIMBLETT, Barbara. 1994. "Maasai on the lawn: tourist realism in East Africa”. Cultural Anthropology 9: 435-70.

CARVALHO, Alan. 2000. "Políticas públicas em turismo no Brasil". Revista Sociedade e Cultura 3(1) e (2): 97-109.

COMUNELLO, Felipe José. 2014. Em busca do frio: o turismo na Região Serrana de Santa Catarina. Tese de Doutorado. Porto Alegre, RS: UFRGS.

COUSIN, Saskia. 2008. L'identité au miroir du tourisme: usages et enjeux des politiques de tourisme culturel. Tese (doutorado) em Antropologia Social e Etnologia. Paris: Ecole des hautes études en sciences sociales.

2011. Les Miroirs du Tourisme: ethnographie de la Touraine du Sud. Paris: Descartes \& Cie.

COUSIN, Saskia; RÉAU, Bertrand. 2009. Sociologie du Tourisme. Paris: La Découverte.

CRUZ, Rita. 2005. "Políticas públicas de turismo no Brasil: território usado, território negligenciado". Revista do Departamento de Geociências 20 (40): 27-43.

ELIAS, Nobert. 1990. “Da sociogênese dos conceitos de 'civilização' e 'cultura'”. In: O Processo Civilizador. Vol. 1. Rio de Janeiro: Jorge Zahar Ed.

ELIAS, Norbert; DUNNING, Eric. 1992. A busca da excitação. Lisboa, Difel.

FLORES, Hilda Agnes; FLORES, Moacyr. 1996. Picada Café. Porto Alegre: Nova Dimensão.

FOUQUET, C. s/d. Der deutsche Einwanderer und seine Nachkommen in Brasilien (1808-1824-1874). São Leopoldo: Institut Hans Staden/Federação dos Centros Culturais "25 de Julho".

1974. O imigrante alemão e seus descendentes no Brasil. São Paulo: Instituto Hans Staden.

GAMPER, Josef Adolf. 1981. "Tourism in Austria: a case study of the influence of tourism on ethnic relations". Ann. Tour. Res. 8: 432-46.

HALL, Michael. 2001. Planejamento turístico: políticas, processos e relacionamentos. São Paulo: Contexto.

HENZ, Aline. 2009. Políticas públicas de turismo no Brasil. Dissertação de Mestrado. Balneário Camboriú, SC: UNIVALI.

INGOLD, Tim. 2011. The Perception of the Environment: Essays on livelihood, dwelling and skill. New York: Routledge.

JOURNET, Nicolas. 2005. “L'argent en famille”. Terrain 45: 5-12. 
LEONG, Wai Teng. 1989. "Culture and the state: manufacturing traditions for tourism". Critical Studies in Mass Communication 6: 355-75.

MACCANNELL, Dean. 1976. The Tourist: A New Theory of the Leisure Class. New York: Schocken. 2nd ed.

NASH, Dennison. 1981. “Tourism as an anthropological subject”. Current Anthropology 22: 461-81. 1996. Anthropology of Tourism. New York: Pergamon.

OBERACKER, K.H. 1957. “Neuschöpfungen der deutschen Sprache in Brasilien”. In: Staden Jahrbuch. São Paulo: Inst. Hans Staden.

25 de julho.

1978. Der deutsche Beitrag zum Aufbau der brasilianischen Nation. São Leopoldo: Fed. dos Centros Culturais

OLIVEN, Ruben George. 1992. A Parte e o Todo: a diversidade cultural no Brasil-Nação. Petrópolis: Vozes.

RADOMSKI, Guilherme. 2010. Certificação participativa e regimes de propriedade intelectual. Tese de Doutorado. Porto Alegre, RS: UFRGS.

SPERB, ngela Tereza; WERLE, Sussana M. M. (coords.). 2004. Na Trilha dos Lírios: escola e comunidade traçam seu futuro através do passado. Picada Café: Secretaria Municipal de Educação, Cultura, Desporto e Turismo.

STRONZA, Amanda. 2001. "Anthropology of Tourism: forging new ground for ecotourism and other alternatives". Annual Review of Anthropology 30: 261-283.

THIESSE, Anne-Marie. 1999. La Création des identités nationales. Europe XVIle siècle-XXe siècle. Paris: Seuil. 2002. "Ficções criadoras: as identidades nacionais". Anos 90 15: 7-23.

TOWNER, J.; WALL, G. 1991. “History and tourism”. Annals of Tourism Research 18: 71-84.

TRESPACH, Rodrigo. 2010. “Memória e História Oral entre os imigrantes alemães no Sul do Brasil: o caso da família Schmitt". Oficina do Historiador 2 (1): 66-77

URRY, John. 1990. The Tourist Gaze: Leisure and Travel in Contemporary Societies. London: Sage Publications. WAGNER, Roy. 2010. "A cultura como criatividade". In: A invenção da cultura. São Paulo: Cosac Naify.

ZANINI, Maria Catarina C. 2007. “Um olhar antropológico sobre fatos e memórias da imigração italiana”. Mana 13(2): 521-547.

ZELIZER, Viviana. 2009. “Dualidades Perigosas”. Mana 15 (1): 237-256. 
Pelos Caminhos da Rota Romântica: Etnografia da constituição de um roteiro turístico no sul do Brasil RESUMO

Este artigo problematiza o processo de constituição do roteiro turístico Rota Romântica ao longo do trajeto de catorze municípios de colonização alemã na região nordeste do estado do Rio Grande do Sul. Busca compreender o modo pelo qual sua configuração suscitou profundas restruturações políticas, econômicas e sociais, colocando em jogo novas relações entre a cidade e seus habitantes, entre natureza e cultura, que passam a informar os cálculos em torno dos benefícios que a indústria turística poderá trazer à região. Metodologicamente, o artigo concentrase na análise de entrevista realizada com seu atual presidente, de materiais de divulgação diversos, bem como da vida social de dois comércios familiares locais em reformulação. Reordenada em torno da nova gramática do mercado turístico, as disputas semânticas trouxeram consequências não somente para a construção de diferentes modalidades ou aptidões turísticas no interior da região, como também para a recomposição da vocação étnica e comercial dos mercados locais.

PALAVRAS-CHAVE: turismo; imigração alemã; mercado; rota romântica; etnografia.

Through the paths of the Romantic Route: an ethnography of the constitution of a touristic itinerary in south Brazil

\section{ABSTRACT}

This article seeks to understand the process of constitution of a touristic itinerary called Romantic Route, along a course of fourteen cities colonized by German immigrants in the 19th century, in the northeast region of the province of Rio Grande do Sul, Brazil. It seeks to acknowledge how its constitution triggered profound political, economical and social transformations, originating new types of relationships between the city and its inhabitants, and between nature and culture, around which calculations of touristic benefits are shaped as indicators of economic development. Methodologically, the texts focuses on the analysis of an interview conducted with its founding president, on different advertisement materials, as well as on the social life of two local familiar enterprises, currently in reformulation. Reorganized around this new grammar of the touristic market, semantic disputes implied in this process had consequences not only for the configuration of different modalities of touristic skills within the region, but also for the rearrangement of the ethnic and commercial aptitudes of local entrepreneurship.

KEY WORDS: tourism; german immigration; market; romantic route; ethnography.

Recebido em 05/02/2014

Aprovado em 11/10/2014 